\title{
SMALL SCALE CHANGE IN MOLLUSK DIVERSITY ALONG A DEPTH GRADIENT IN A SEAGRASS BED OFF CABO FRIO, (SOUTHEAST BRAZIL)*
}

\author{
Joel Christopher Creed** and Monique Kinupp \\ Universidade do Estado do Rio de Janeiro - Laboratório de Ecologia Marinha Bêntica \\ Departamento de Ecologia - IBRAG, PHLC Sala 220 \\ (Rua São Francisco Xavier 524, 20559-900 Rio de Janeiro, RJ, Brasil) \\ **Corresponding author: jcreed@uerj.br
}

\begin{abstract}
A B S TR A C T
We know little about animal communities in seagrass beds in the southeast Atlantic. The aim of the current study was to characterize and quantify the mollusk assemblages within these unique tropical seagrass habitats at a spatial scale fine enough to relate change in assemblage structure to gradients in exposure to air/depth. The study was carried out off Cabo Frio, Southeast Brazil. A $1250 \mathrm{~m}^{2}$ area vegetated by the seagrass Halodule wrightii was defined $(50 \mathrm{~m}$ parallel to the shoreline $\times 25 \mathrm{~m}$ distance from the shore margin). Twenty-six transects were established and the sampling carried out in order to characterize and to quantify the associated mollusk fauna. The mollusk assemblage presented overall density, density of key species and mean richness which increased systematically along the onshore-to-offshore gradient. Furthermore over the short spatial distance of the study the mollusk assemblage changed sufficiently for ordination to detect different assemblages.
\end{abstract}

\section{RESUMO}

Há pouco conhecimento sobre a comunidade animal em bancos de fanerógamas marinhas no Atlântico sudeste. O presente estudo teve como objetivo caracterizar e quantificar assembléias de Mollusca nesses habitats únicos, utilizando uma escala espacial sensível suficiente para relacionar mudança na estrutura da assembléia aos gradientes em exposição ao ar/profundidade. O estudo foi realizado em Cabo Frio, no sudeste do Brasil. Delimitou-se uma área de vegetação de Halodule wrightii de $1250 \mathrm{~m}^{2}(50 \mathrm{~m}$ paralelo ao costão $\times 25 \mathrm{~m}$ distância da orla). Foram estabelecidos 26 transectos e realizada a amostragem, de modo a caracterizar e quantificar a malacofauna. A assembléia apresentou uma densidade, densidade de espécies chaves e riqueza média que aumentou sistematicamente ao longo do gradiente orla-mar. Além disso, em escala espacial curta, a assembléia de Mollusca mudou suficientemente que, através de uma ordenação, se detectou diferenças entre assembléias.

Descriptors: Assemblage, Brazil, Diversity, Halodule wrightii, Mollusks.

Descritores: Assembléia, Brasil, Diversidade, Halodule wrightii, Mollusca.

\section{INTRODUCTION}

The abundance and diversity of benthic communities associated with seagrass beds are greater than those in sediments without seagrass (STONER, 1980; ORTH et al., 1984, EDGAR et al., 1994; CONNOLY, 1997) because the beds are environmentally heterogeneous and biologically productive systems on soft bottoms. Seagrass beds are highly productive (BELL; POLLARD, 1989), stabilize sediments (FONSECA et al., 1982) and compact the substrate, providing shelter, refuge and nursery space for marine animals (ORTH et al., 1984).

Little is known about the ecology of the seagrass ecosystems of South America (CREED, 2003). Halodule wrightii Ascherson is the most

(*) Paper presented at the $2^{\text {st }}$ Brazilian Congress of Marine Biology, on 24-28 May. Búzios, RJ, Brazil. 2009. common seagrass in the state of Rio de Janeiro and probably constitutes the largest seagrass beds off Cabo Frio (CREED, 1999). The local beds are situated in a channel which links the Araruama Lagoon to the sea. The Araruama Lagoon is the largest hypersaline coastal lagoon in Brazil and one of the largest in the world (KJERFVE et al., 1996). Furthermore, the Cabo Frio region sporadically receives cold, nutrient rich waters due to coastal upwelling. Consequently, because of the bidirectional flow in this estuarine system and local upwelling, temperature, salinity and nutrient load vary considerably, constituting an atypical tropical oceanographic setting and creating a habitat that is probably unique in the southwestern Atlantic. Few data exist relating to the fauna associated with Halodule wrightii in the southwestern Atlantic or to the trophic interactions between this seagrass and the fauna (CORBISIER, 1994; JUNQUEIRA et al., 1997). CORBISIER (1994) 
compared the abundance of macrozoobenthos within a Halodule wrightii (Ascherson) bed with that in bare sand at the Praia do Codó, São Paulo. JUNQUEIRA et al. (1997) studied the size, structure and density of a population of Lytechinus variegatus Lamarck in the $H$. wrightii bed at Cabo Frio, Rio de Janeiro. CREED (2000) quantified the abundance of Cerithium atratum and hermit crabs to estimate the ecological importance of cerith shells as a substratum available for sessile invertebrates at the same site. CARVALHO and VENTURA (2002) also studied the reproductive cycle and gametogenesis of Asterina stellifera Möbius in the $H$. wrightii bed at this site. OMENA and CREED (2004) investigated the polychaete assemblage structure of six seagrass beds (Halodule wrightii) along the coast of Rio de Janeiro.

Despite these studies we still know rather little about how the associated flora and fauna utilize the seagrass beds as habitat or about the trophic interactions between the component species. Consequently, an ongoing program aimed at modeling seagrass food webs in the southwestern Atlantic through an intensive study of the seagrass habitat at Cabo Frio is currently being undertaken. Due to the ecological importance of the seagrass beds the site has also been monitored as part of SeagrassNet Global Seagrass Monitoring Program, which aims to establish seagrass monitoring sites worldwide and track the status of seagrasses as a measure of the trends in environmental health by using a standard protocol covering distribution, species composition, and abundance (SHORT et al., 2004, 2005, 2006).The program started in 2001 in the Western Pacific and in 2002 in Brazil.

Using criteria proposed by PETERSEN (1913) and THORSON (1957) the study of benthic ecosystems can be undertaken utilizing a subset of animals (assemblage) that represent the community. Mollusks, among the benthic macrofauna, are a characteristically rich phylum that plays an important role in benthic processes and whose species interact at different trophic levels (GONÇALVES; LANA,
1991). Thus, mollusks have been used as community surrogates in these ecosystems because they are a group of animals with a wide ecological spectrum and which use a considerable portion of environmental resources due to their distribution and diversity. Furthermore, they are important in food chains because they can be detritivores, herbivores, carnivores or omnivores (LEVINTON, 1995).

In the present study we tested the hypothesis that on small spatial scales a strong onshore-tooffshore gradient in relative environmental stability, caused by exposure to air/depth, results in a positive relationship between mollusk assemblage descriptors (density, richness, diversity) and distance from shore. As part of a wider ranging study aimed at modeling the seagrass food web, a secondary aim of the study was to qualify and quantify the mollusk assemblages within these unique tropical Southwest Atlantic seagrass habitats in order to identify key species and probable trophic links.

\section{Materials And Methods}

The study area was situated on the Ilha do Japonês, Cabo Frio, on the tropical southeast coast of Brazil in Rio de Janeiro State $\left(22^{\circ} 52.925 \mathrm{~S}\right.$, $42^{\circ} 00.200 \mathrm{~W}$ ). The Ilha do Japonês is situated in the Itajuru Canal that links the Araruama lagoon to the sea (Fig. 1). The seagrass beds are essentially intertidal. Seawater temperatures vary from 17 to $32.5^{\circ} \mathrm{C}$, depending on the tidal cycles and on the coastal upwelling conditions typical of the Cabo Frio region (characterized by low water temperatures). Seawater salinity varies from 35 to 40 as the lagoon is hypersaline. The lowest spring tides occur during the day from April to October and tidal range is $1.4 \mathrm{~m}$. Light intensity at the sediment-water column interface can reach 3160 Lux (lumen. $\mathrm{m}^{-2}$ ). The area is subjected to a bi-directional tidal flow in and out of the lagoon and is protected from the wind (CREED, 1999).

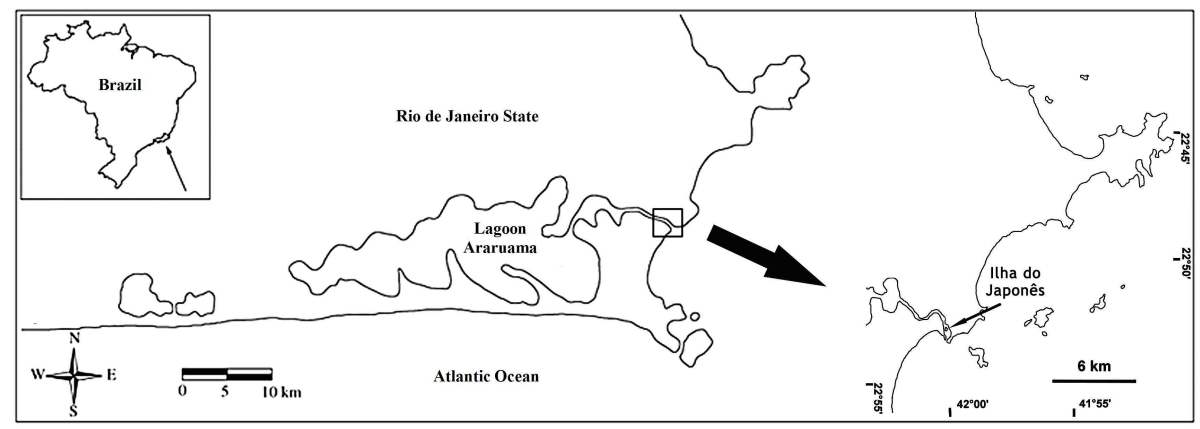

Fig. 1. Map showing the location of the study site at Ilha do Japonês, Cabo Frio, Brazil. 
An intensive collection of samples was carried out in October 1999 in order to incorporate small scale spatial variation in the assemblages due to patches as well as systematic gradients in exposure to air and water depth. The study area is an environment some parts of which are subjected to tidal currents, periods of exposure to air during low tides and high light intensity. An area of $26 \times 50 \mathrm{~m}\left(1250 \mathrm{~m}^{2}\right)$ with many patches of the seagrass Halodule wrightii was delimited starting $25 \mathrm{~m}$ from the shore margin of the Ilha do Japonês and running out $26 \mathrm{~m}$. Twenty-six parallel $50 \mathrm{~m}$ long transects were placed at $1 \mathrm{~m}$ intervals within the area parallel to the coast and each transect was sampled every $1 \mathrm{~m}$, forming a sampling grid of $1 \mathrm{~m}$ intervals in each direction. Samples were collected with a PVC corer $(160 \mathrm{~cm} 2,15 \mathrm{~cm}$ depth), totaling 26 transects with 51 samples each. The samples were carefully washed through $1 \mathrm{~mm}$ sieves in the field and later fixed with formaldehyde $(6 \%)$ and stored in labeled plastic bags. In the laboratory the samples were sorted and mollusks separated and stored in alcohol (70\%). The mollusks were identified and quantified to the lowest taxonomic level, using the classification adopted by RIOS (1994). We considered only the live animals.

The assemblage structure was characterized by using mean density and frequency of occurrence, the number of dominant species, richness, diversity (by the Simpson index) and community evenness. Frequency of occurrence $(1 / \mathrm{S}$, where $\mathrm{S}$ is the total number of species in the assemblage) was used to identify dominant taxa $(\geq 0.027)$. Pearson's Correlation Coefficient was used to investigate the relationship between density and community indices and distance from shore (a surrogate for the combined effects of air exposure and depth, as the shore-to-sea gradient was constant over the study area).
To test for differences in assemblage structure with distance from the shore we carried out an ordination analysis using non-metric MultiDimensional Scaling (MDS) on transect means (CLARKE; WARWICK, 1994) using the program PRIMER; the Bray-Curtis similarity index was calculated on standardized square root transformed data. Significant differences were tested between groups using ANOSIM (Factor $=$ Distance, grouped in transects: Group $1=$ T25-T30, Group $2=$ T31-35, Group 3 = T36-T40, Group $4=$ T41-T45, Group 5 T46-T50).

\section{Results}

We found the Classes Polyplacophora, Gastropoda and Bivalvia in samples collected on the Ilha do Japonês. Altogether 37 taxa were identified, 31 taxa at the species level, 5 at the genus level, and 1 taxon at the family level (Table 1). Of the 31 species identified (classified into 29 genera and 25 families), 15 belonged to Bivalvia, 14 to the Gastropoda and two taxa to the Polyplacophora class.

The mean density of mollusks was 57.68 individuals per sample. The gastropod Cerithium atratum (Born, 1778) was the most abundant species, having a mean density of 30.33 individuals per sample, followed by the bivalves Divaricella quadrisulcata (Orbigny, 1842) (17.91 individuals per sample), Ostrea puelchana Orbigny, 1841 (3.69 individuals per sample), Codakia orbiculares (Linnaeus, 1758) (3.30 individuals per sample) and Tellina lineata Turton, 1819 (1.28 individuals per sample). These five species accounted for $97.84 \%$ of the total mollusk fauna (Fig. 2). Overall there was a highly significant increase in mollusk density with distance from the shore/depth (Pearson's $r=0.86, \mathrm{p}$ $<0.001)$.

Table 1. List of species of mollusks collected at Ilha do Japonês, Brazil, according to Rios (1994).

\begin{tabular}{|c|c|}
\hline Taxa & Taxa (cont) \\
\hline Stenoplax cf. purpurascens (C.B. Adms, 1845) & Pinctada cf. imbricata Roding, 1798 \\
\hline Ischnochiton striolatus (Gray, 1828) & Isognomon bicolor (CB Adams, 1845) \\
\hline Tegula viridula (Gmelin, 1791) & Atrina seminuda (Orbigny, 1846) \\
\hline Astraea tecta olfersii (Philippi, 1846) & Ostrea puelchana Orbigny, 1841 \\
\hline Neritina virginea (Linnaeus, 1758) & Lucina pectinata (Gmelin, 1791) \\
\hline Cerithium atratum (Born, 1778) & Codakia orbiculares (Linnaeus, 1758) \\
\hline Crepidula aculeata (Gmelin, 1791) & Divaricella quadrisulcata (Orbigny, 1842) \\
\hline Capulus incurvatus (Gmelin, 1791) & Diplodonta semiaspera (Philippi, 1836) \\
\hline Polinices lacteus (Guilding, 1833) & Diplodonta sp. Bronn, 1831 \\
\hline Polinices sp. Montfort, 1810 & Laevicardium brasilianum (Lamarck, 1819) \\
\hline Cymatium sp. Roding, 1798 & Tellina lineata Turton, 1819 \\
\hline Morula nodulosa (CB Adams, 1845) & Tellina sp. Linnaeus, 1758 \\
\hline Thais rustica (Lamarck,1822) & FAMÍLIA: SEMILIDAE \\
\hline Anachis fenneli Radwin, 1968 & Chione cancellata (Linnaeus, 1767) \\
\hline Nassarius albus (Say,1826) & Chione paphia (Linnaeus, 1767) \\
\hline Nassarius vibex (Say,1826) & Anomalocardia brasiliana (Gmelin, 1791) \\
\hline Leucozonia nassa (Gmelin, 1791) & Pitar fulminatus (Menke,1828) \\
\hline Bulla striata Bruguìere, 1792 & Entodesma sp. Philippi, 1845 \\
\hline
\end{tabular}




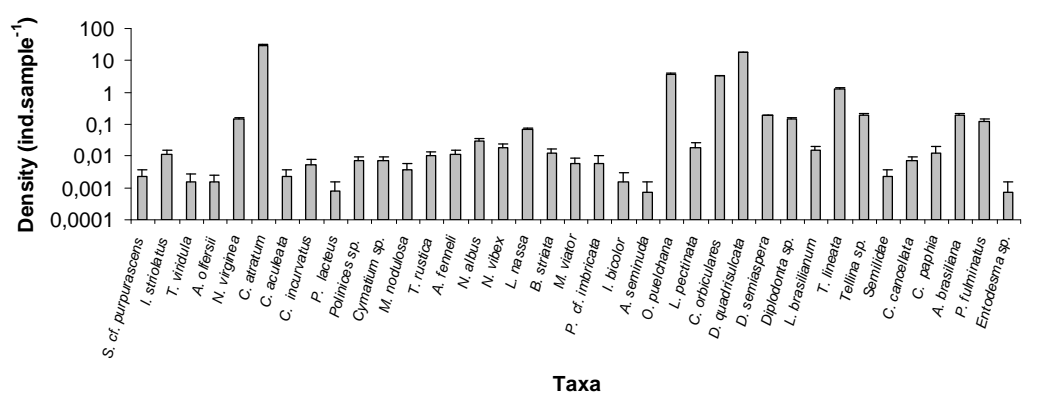

Fig. 2. Mean density of taxa (logarithmic scale) found in this study. Bars= SE.

In Table 2 the overall mean density per sample and frequency of occurrence of taxa found in this study are presented. Positive and highly significant correlations between the distance from shore (corresponding to depth/exposure) and density of the two most abundant species were found (Cerithium atratum Pearson's $\mathrm{r}=0.87$, $\mathrm{p}<0.001$; Divaricella quadrisulcata, Pearson's $\mathrm{r}=0.69, \mathrm{p}$ $<0.001$ ) (Fig. 3). As well as being the most dense, the gastropod Cerithum atratum was also the most frequent species with a relative frequency of $52.49 \%$ in the samples. In descending order it was followed by Divaricella quadrisulcata (31\%), Ostrea puelchana $(6.40 \%)$, Codakia orbiculares $(5.72 \%)$ and Tellina lineata $(2.22 \%)$. The other species found in this study occurred in less than $1 \%$ of samples (Fig. 4). Based on the frequency data, four species were considered dominant, because they had a frequency above 0.027 : C. atratum (0.52), D. quadrisulcata (0.31), $O$. puelchana (0.06), and C. orbicularis (0.05).

Table 2. Mean density per sample and frequency (\%) of mollusk species found in a seagrass bed at Cabo Frio, Brazil.

\begin{tabular}{|c|c|c|}
\hline & "Mean Density & Frequency (\%) \\
\hline Cerithium atratum & 30.34 & 52.49 \\
\hline Divaricella quadrisulcata & 17.92 & 31.01 \\
\hline Ostrea puelchana & 3.70 & 6.40 \\
\hline Codakia orbiculares & 3.31 & 5.73 \\
\hline Tellina lineata & 1.28 & 2.22 \\
\hline Tellina sp. & 0.19 & 0.34 \\
\hline Anomalocardia brasiliana & 0.19 & 0.32 \\
\hline Diplodonta semiaspera & 0.19 & 0.32 \\
\hline Diplodonta sp. & 0.15 & 0.25 \\
\hline Neritina virgínea & 0.14 & 0.25 \\
\hline Pitar fulminatus & 0.13 & 0.22 \\
\hline Leucozonia nassa & 0.07 & 0.12 \\
\hline Nassarius albus & 0.03 & 0.05 \\
\hline Nassarius vibex & 0.02 & 0.03 \\
\hline Lucina pectinata & 0.02 & 0.03 \\
\hline Laevicardium brasilianum & 0.02 & 0.03 \\
\hline Bulla striata & 0.01 & 0.02 \\
\hline Chione paphia & 0.01 & 0.02 \\
\hline Ischnochiton striolatus & 0.01 & 0.02 \\
\hline Anachis fenneli & 0.01 & 0.02 \\
\hline Thais rústica & 0.01 & 0.02 \\
\hline Polinices sp. & 0.01 & 0.01 \\
\hline Cymatium sp. & 0.01 & 0.01 \\
\hline Chione cancellata & 0.01 & 0.01 \\
\hline Musculus viator & 0.01 & 0.01 \\
\hline Pinctada cf. imbricata & 0.01 & 0.01 \\
\hline Capulus incurvatus & 0.01 & 0.01 \\
\hline Morula nodulosa & 0.00 & 0.01 \\
\hline Stenoplax cf. purpurascens & $<0.01$ & $<0.01$ \\
\hline Crepidula aculeata & $<0.01$ & $<0.01$ \\
\hline Semilidae & $<0.01$ & $<0.01$ \\
\hline Tegula viridula & $<0.01$ & $<0.01$ \\
\hline Astraea olfersii & $<0.01$ & $<0.01$ \\
\hline Isognomon bicolor & $<0.01$ & $<0.01$ \\
\hline Polinices lacteus & $<0.01$ & $<0.01$ \\
\hline Atrina seminuda & $<0.01$ & $<0.01$ \\
\hline Entodesma sp. & $<0.01$ & $<0.01$ \\
\hline
\end{tabular}



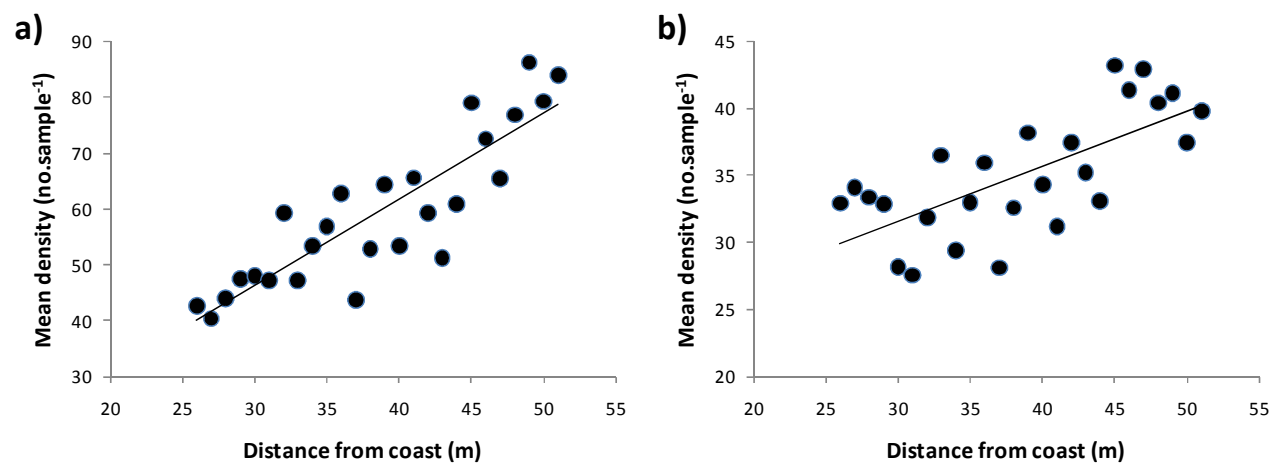

Fig. 3. Dispersion diagram of mean density per transect and distance from shore for (a) Cerithium atratum (b) Divaricella quadrisulcata in a seagrass bed at Cabo Frio, Brazil.

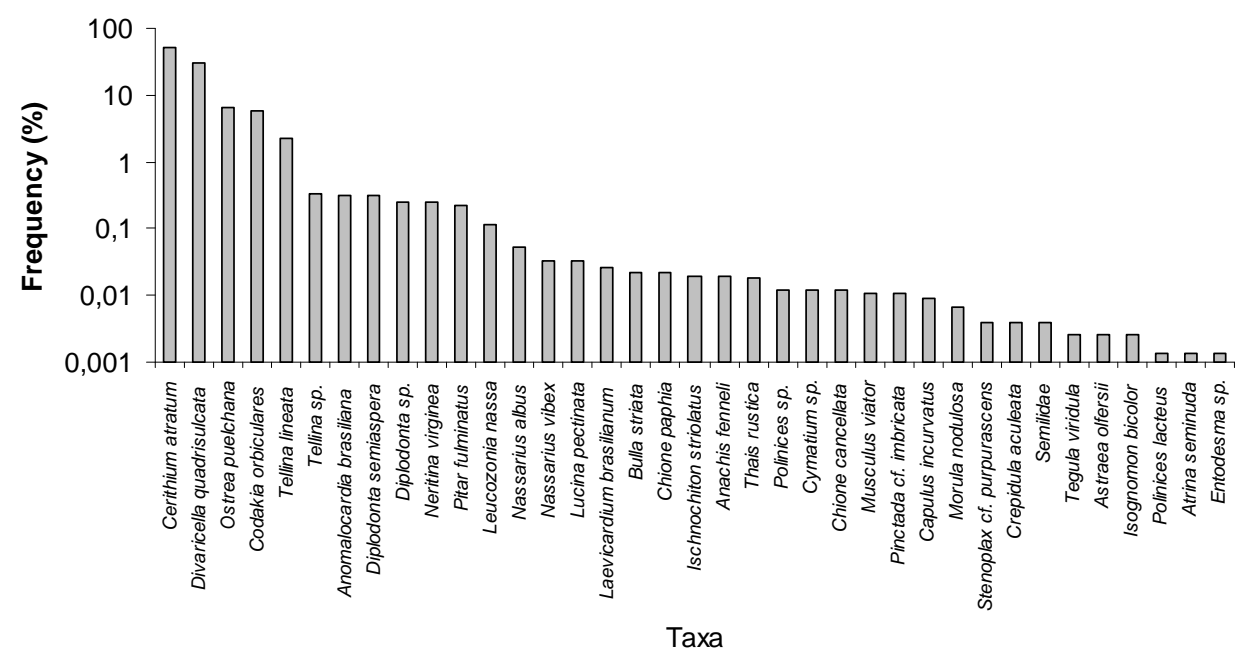

Fig. 4. Relative frequencies (logarithmic scale) of mollusks at Ilha do Japonês, Cabo Frio, Brazil.

No significant correlation between total richness per transect and distance from the shore was found (Pearson's $r=0.076, p=0.71$ ) (Fig. 5a). However, there was a positive and highly significant correlation between mean richness per sample and distance from the shore (Pearson's $r=0.56, p=0.003$ ). All transects showed relatively low values of the Simpson Index (Fig. 5b). The low diversity values were explained by the low evenness (Fig. 5b).

MDS indicated that the assemblage was fairly homogeneous with the overlapping of groups (Fig. 6). However, ANOSIM results (Global R = 0.149 , significance level of sample statistic $=3.3 \%$ ) demonstrated significantly different groups in shallow frequently exposed conditions (Group 1, 25-30 m) when compared to deeper less frequently exposed transects (Group 5, 45-50 m) and $\mathrm{R}$ values of the pairwise tests suggested that the assemblage changed systematically in relation to the onshore-to-offshore gradient (Table 3, Fig. 6).

\section{DisCUSSION}

The mollusk assemblage in the seagrass meadow at Cabo Frio presented overall mollusk density, density of key species and mean richness which increased systematically along the onshore-tooffshore gradient. This gradient was due to influences imposed by the regime of exposure to air and consequent gradients in temperature, desiccation, light and nutrient and gas availability. Furthermore, over the short spatial distance of the study the mollusk assemblage changed sufficiently for ordination to detect different mollusk assemblages. 
a)
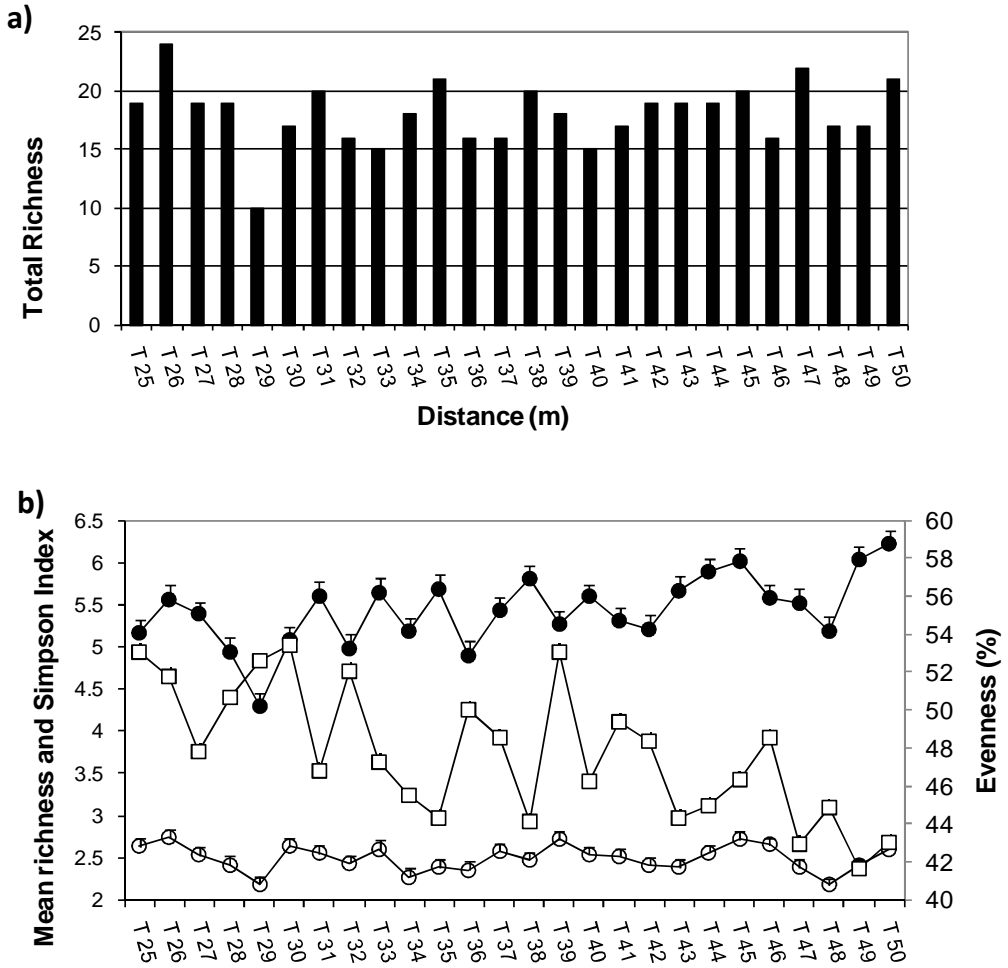

Distance (m)

$\rightarrow-$ Mean Richness $\multimap$ Index Simpson $\multimap-$ Evenness

Fig. 5(a). Total mollusk richness per transect (b) mean mollusk richness per sample, Simpson Index and evenness with distance from shore $(\mathrm{T})$ in a seagrass bed at Cabo Frio, Brazil. Bars= SE.

Table 3. Pairwise tests of oneway analysis of similarity of mollusk assemblages between shore distance groups at Cabo Frio, Brazil. Group $1=25-30 \mathrm{~m}$, Group 2 = 31-35 $\mathrm{m}$, Group 3 = 36-40 m, Group $4=41-45 \mathrm{~m}$, Group 5 46$50 \mathrm{~m}$.

\begin{tabular}{lll}
\hline Groups & R Statistic & Significance Level \% \\
\hline 1,2 & 0.056 & 32.9 \\
1,3 & 0.232 & 6.5 \\
1,4 & 0.205 & 5.6 \\
1,5 & 0.437 & 1.5 \\
2,3 & 0.048 & 31. \\
2,4 & 0.04 & 34.1 \\
2,5 & 0.336 & 4.8 \\
3,4 & -0.02 & 52.4 \\
3,5 & -0.056 & 62.7 \\
4,5 & 0.036 & 34.9 \\
\hline
\end{tabular}




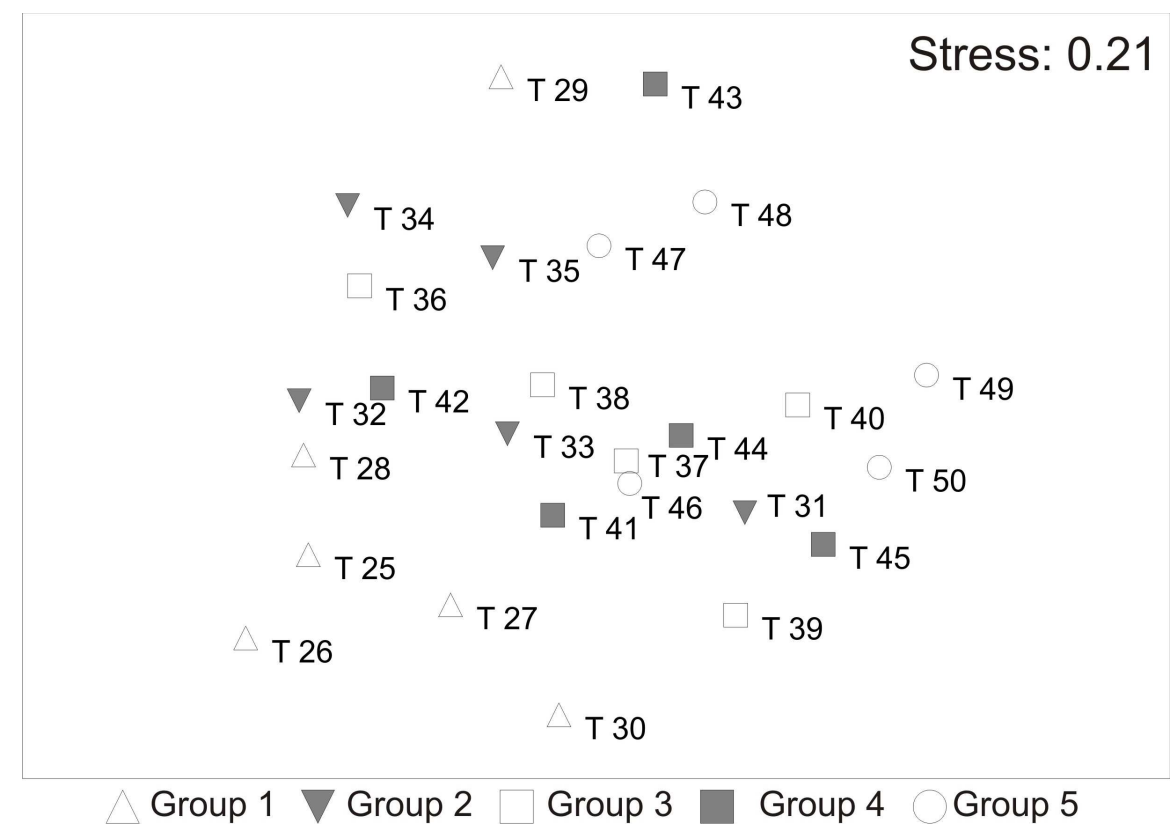

Fig. 6. MDS configuration of 26 transects (assemblage means) in a seagrass bed at Cabo Frio, Brazil. Groups (used in oneway analysis of similarity) are organized by distance from shore: Group $1=25-30 \mathrm{~m}$, Group 2 = 31-35 m, Group 3 = 36-40 m, Group 4 = 41-45 m, Group 5 46-50 m.

The spatial distribution of the benthic fauna at the intertidal level is strongly affected by the variation in physico-chemical conditions (REISE, 1985; PETERSON, 1991; WILSON JR, 1991) such as sediment stability and composition (resulting from tidal currents) and the frequency and length of exposure at low tide (imposed by the tidal pattern). Studies have, moreover, demonstrated that the abundance and diversity of benthic communities associated with the seagrass beds are higher than in sediments without seagrass (STONER, 1980; ORTH et al., 1984; EDGAR et al., 1994; CONNOLY, 1997). Seagrasses provide physical structure on otherwise often largely featureless sediment bottoms, enhancing community diversity, biomass, and primary and secondary production (MARBÀ et al., 2006).

The assemblage of mollusks in the Halodule wrightii bed at Cabo Frio was highly dense. The gastropod Cerithium atratum exhibited the highest density due to the abundance of food found in the seagrass meadows (ORTH et al., 1984) as C. atratum is an algal-detritus feeder (HOUBRICK, 1974). Furthermore, the seagrasses provide a refuge from predation, as denser areas provide more protection. In response to predation, $C$. atratum burrows into the sediment during the day and rises to the surface of the sediment and onto $H$. wrightii blades at night (HOUBRICK, 1992; KLUMPP et al., 1992). Another important relationship between seagrass and $C$. atratum is the availability of areas for egg deposition on seagrass blades, as $C$. atratum often lays egg strings on seagrasses (RIOS, 1994). Moreover, larval settling may be facilitated because seagrasses can reduce current speed substantially (FONSECA; FISHER, 1986). Although $C$. atratum exhibited a positive and highly significant correlation with distance from shore, the gastropod does have adaptations and strategies to avoid direct air-exposure and occurred in large numbers throughout the intertidal study area. A conceptual model which identifies the spatial and functional interactions of the main mollusk species with the seagrass at Cabo Frio, Brazil is presented in Figure 7 and demonstrates the key role of $C$. atratum.

As well as $C$. atratum, the bivalves $D$. quadrisulcata, $C$. orbicularis and $T$. lineata were highly abundant in the seagrass habitat at Cabo Frio. They use their feet to excavate and construct a channel in the sediment surface and are spatially associated with the seagrass rhizosphere (Fig. 7). The seagrasses 
provide an ideal habitat for these mollusks, because roots and interlaced rhizomes provide better shelter and protection from predators than unvegetated areas (JACKSON, 1972; BARNES, 1996; BARNES; HICKMAN, 1999). Mollusk assemblages living on rhizomes and within the sediment are considered to be more diverse due to a greater habitat complexity and show less seasonal change due to less stressful and more constant environmental conditions. These observations are corroborated by a high density of bivalves in the $H$. wrightii meadow.

As well as these bivalves, O. puelchana (a species with high density in the study area too) was found almost exclusively on Cerithium atratum shells (Fig. 7). According to CREED (2000), this oyster uses C. atratum shells as the main hard-substrate available for attachment and growth within this soft bottom habitat and the oysters can subsequently grow larger than their host (personal observations) which we presume would have a negative effect on the growth or survival of the basibiont.

The study showed that $C$. atratum and $D$. quadrisulcata exhibited the highest relative frequencies, revealing these to be dominant species. They are the two most successful mollusk species in the assemblage and as they are abundant prey for predators they can be considered key species in the study area. O. puelchana, C. orbicularis, Tellina lineata were also frequent and important to the assemblage. Despite the dominance of a few species of mollusk, the MDS and ANOSIM analyses confirmed that the mollusk assemblages as a whole change along the exposure gradient on quite short spatial scales.

The highest density and mean richness of mollusks were recorded on transects farther from the coast. REYES-BARRAGÁN AND SALAZARVALLEJO (1989) also observed that the mean richness of species was proportional to the distance from the coast in Halodule beds in Mexico. According to ANSELL ET AL. (1980) during low tide a large part of intertidal seagrass beds can be exposed the effect of the sun, rain and wind, and thus many species may be exposed to constant disturbances, such as suspension or remobilization of the sediments, desiccation and fluctuations in salinity. According to ANSELL ET AL. (1980), the thermal tolerance of mollusks is usually inversely proportional to their bathymetric distribution. The study area is subjected to tidal currents, periods of exposure to air during low tides and high light intensity. JACKSON (1972) described the existence of a direct relationship between predation and diversity of mollusks in the seagrass beds in Jamaica, showing that predation tends to reduce the dominance and increase the diversity and equitability of the community. It is possible that predator gradients were present in the seagrass bed at Cabo Frio as we found seven families of predatory gastropods (Naticidae, Cymaltidae, Muricidae, Thaididae, Columbellidae, Nassariidae and Fasciolariidae) among them Leucozonia nassa, which is a predator of $C$. atratum. However, L. nassa was only found at low densities throughout the study area.

The abundance of mollusk assemblages at Cabo Frio reflected the heightened primary productivity due to the presence of the seagrass. Many previous studies conducted in seagrass beds (Halodule decipiens, Halodule wrightii, Heterozostera tasmania, Zostera muelleri and Zostera marina) have reported a greater diversity of fauna in areas with seagrasses (CORBISIER, 1994; EDGAR et al., 1994; WEBSTER et al., 1998; CASARES; CREED, 2008) than in areas without seagrasses. It would seem that because of the increased productivity in these systems, community structure is highly skewed in rank abundance (CASARES; CREED, 2008).

In summary, the nearshore mollusk assemblage at Cabo Frio, when examined on a small spatial scale, is influenced by gradients caused by exposure to air which result in systematic changes in density, richness and assemblage structure. The mollusk assemblage was considered to be abundant and quite rich due to the detritus provided by the seagrass, although four species dominated the rank abundance and these demonstrated clear spatial and/or functional interactions with the seagrass and assemblage elements. This seagrass-mollusk assemblage merits more detailed studies focusing on the investigation of important ecological factors such as predation, competition, larval supply in the relationship with seagrass through controlled manipulative experiments.

\section{ACKNOWLEDGEMENTS}

We would like to thank the staff and students of the Laboratório de Ecologia Marinha Bêntica, Universidade do Estado do Rio de Janeiro. This research was supported by the Conselho Nacional de Desenvolvimento Científico e Tecnológico - CNPq and the Fundação Carlos Chagas Filho de Amparo à Pesquisa do Estado do Rio de Janeiro - FAPERJ. M. Kinupp received an undergraduate scholarship from the Programa Institucional de Bolsas de Iniciação Científica da Universidade do Estado do Rio de Janeiro, PIBIC-UERJ. We also thank two anonymous reviewers for comments which improved the manuscript.

\section{REFERENCES}

ANSELL A.; FRENKIEL, L.; MOUËZA, M. Seasonal changes in tissue weight and biochemical composition for the bivalve Donax trunculus L. on the Algerian coast. J. expl mar. Biol. Ecol., v. 45, p. 105-116, 1980. 
BARNES, P. The role of nutrition in the distribution of chemoautotrophic bacteria-Lucinid bivalve symbiosis in Bermuda. Amer. Zool., v. 36, p. 403, 1996.

BARNES, P.; HICKMAN, C. S. Lucinid bivalves and marine angiosperms: a search for causal relationships. In: WALKER, D.I.; WELLS, F.E.(Ed.). The seagrass Flora and Fauna of Rottnest Island, Western Australia. Perth: Western Australian Museum, 1999. p. 215-238.

BELL, J. D.; POLLARD, D. A. Ecology of fish assemblages and fisheries associated with seagrass. In: LARKUM, A W. D.; MCCOMB A. J.; SHEPHERD, S.A. (Ed.) Biology of seagrasses: a treatise on the Biology of seagrasses with special reference to the Australian Region. 1989, p. 565-609.

CARVALHO, A. L. P. S.; VENTURA, C. R. R. The reproductive cycle of Asterina stellifera (Möbius) (Echinodermata: Asteroidea) in the Cabo Frio region, southeastern Brazil. Mar. Biol., v. 141, p. 947-954, 2002.

CASARES, F. A.; CREED, J. C. Do small seagrasses enhance density, richness, and diversity of macrofauna? J. coast. Res., v. 24, p. 790-797, 2008.

CLARKE, K. R.; WARWICK, R. M. Similarity-based testing for community pattern: the 2-way layout with no replication. Mar. Biol., v.118, p.167-176, 1994.

CONNOLY, R. M. Differences in composition of small, motile invertebrate assemblages from seagrass and unvegetated habitats in a southern Australian estuary. Hydrobiologia, v. 346, p.137-148, 1997.

CORBISIER, T. N. Macrozoobenthos da Praia do Codó (Ubatuba, SP) e a presença de Halodule wrightii Ascherson. Bolm Inst. Oceanogr., v. 42, p.99-111, 1994.

CREED, J. C. Distribution, seasonal abundance and shoot size of the seagrass Halodule wrightii near its southern limit at Rio de Janeiro state, Brazil. Aquatic Bot., v. 65, p. 47-58, 1999.

CREED, J.C. Epibiosis on cerith shells in a seagrass bed: correlation of shell occupant with epizoite distribution and abundance. Mar. Biol., v. 137, p. 775-782, 2000.

CREED, J. C. The seagrasses of South America: Brazil, Argentina and Chile. In: GREEN, E. P.; SHORT, F. T. (Ed). World Atlas of seagrasses. Berckeley, CA: University of California Press, 2003. p 243-250.

EDGAR, G.J.; WATSON, G.; HAMMOND, L.S.; SHAW, C. Comparisons of species richness, size-structure and production of benthos in vegetated and unvegetated habitats in Western Port, Victoria. J. expl mar. Biol. Ecol., v.176, p. 201-226, 1994.

FONSECA, M. S.; FISHER, J. S.; ZIEMAN, J. C.; THAYER, G.W. Influence of the seagrass Zostera marina L., on current flow. Estuar. coast. Shelf Sci., v. 15, p.351-364, 1982

FONSECA, M. S.; FISHER, J. S. A comparison of canopy friction and sediment movement between four species of seagrass with reference to their ecology and restoration. Mar. Ecol. Prog. Ser., v. 29, p.15-22, 1986.

GONÇALVES, E. M.; LANA, P. C. Padrões de distribuição de Bivalvia e Gastropoda na plataforma continental da costa sudeste do Brasil $\left(24^{\circ} \mathrm{S}-27^{\circ} \mathrm{N}\right)$; Nerítica, v. 6, p. 73-92, 1991

HOUBRICK, J. R. Growth studies on the genus Cerithium (Gastropoda: Prosobranchia) with notes on ecology and microhabitats. Nautilus., v. 88, p. 14-27, 1974.
HOUBRICK, J. R. Monograph of the genus Cerithium Bruguiere in the Indo-Pacific (Cerithiidae: Prosobranchia). Smithson. Contrib. Zool., v. 510, p. 1$211,1992$.

JACKSON, J. B. C. The ecology of the mollusks of Thalassia communities, Jamaica, West Indies. II. Molluscan population variability along an environmental stress gradient. Mar. Biol., v. 14, p. 304-372, 1972.

JUNQUEIRA, A. D. R.; VENTURA, C. R. R.; DE CARVALHO, A. L. P. S.; SCHMIDT, A. J. Population recovery of the sea urchin Lytechinus variegates in a seagrass flat (Araruama Lagoon, Brazil): The role of recruitment in a disturbed environment. Invert. Reprod. Dev.., v. 31, p. 143-150, 1997.

KJERFVE, B.; SCHETTINI, C. A. KNOPPERS, B.; LESSA, G.; FERREIRA, H.O. Hydrology and salt balance in a large, hypersaline coastal lagoon: Lagoa de Araruama, Brazil. Estuar. coast. Shelf Sci., v.42, p. 701-725, 1996.

KLUMPP, D. W.; SALITA ESPINOSA, J. S.; FORTES, M. D. The role of epiphytic periphyton and macroinvertebrate grazers in the trophic flux of a tropical seagrass community. Aquatic Bot., v. 43, p. 327-349, 1992.

LEVINTON, J. S. Marine Biology. Function, Biodiversity, Ecology. New York, Oxford University Press, 1995, $420 \mathrm{p}$.

MARBÂ, N.; HOLMER, M.; GACIA, E.; BARRON, C. Seagrass beds and coastal biogeochemistry. In: LARKUM, A. W. D.; ORTH R. J.; DUARTE C. M. (Ed.). Seagrasses: Biology, Ecology and conservation. Netherlands: Springer, 2006. p. 135-157.

OMENA, E.; CREED, J. C. Polychaete fauna of seagrass beds (Halodule wrightii Ascherson) along the coast of Rio de Janeiro (Southeast Brazil). Mar. Ecol., v. 25, p. 273-288, 2004.

ORTH, R. J.; HECK, K. L.; VAN MONTFRANS, J. Faunal communities in seagrass beds - A review of the influence of plant structure and prey characteristics on predator prey relationships. Estuaries., v. 7, p. 339-350, 1984.

PETERSEN, C. G. The animal communities of the sea bottom and their importance for marine zoogeography. Rept Danish Biol. Stat., v. 21, p.44, 1913.

PETERSON, C.H. Intertidal zonation of marine invertebrates in sand and mud. Am. Scient., v. 79, p. 236-248, 1991.

REISE, K. Tidal flat ecology - an experimental approach to species interactions. Berlin: Springer Verlag, 1985. $191 \mathrm{p}$.

REYES-BARRAGÁN, M. P.; SALAZAR-VALLEJO, S. I. Benthos asociado al pastizal de Halodule (Potamogetonaceae) en Laguna de La Mancha, Veracruz, México. Revta Biol. trop., v. 38, p. 167-173, 1989.

RIOS, E. C. Seashells of Brazil. Rio Grande: Fundação Universidade do Rio Grande, RS, 1994. 368 p.

SHORT, F.T.; MCKENZIE L.J.; COLES R.G.; GAECKLE J.L. SeagrassNet Manual for scientific monitoring of Seagrass habitat - Western Pacific. Cairns, Australia: Queensland Department of Primary Industries, 2004. 71

SHORT, F. T.; MCKENZIE L. J.; COLES, R .G.; GAECKLE, J. L. SeagrassNet Manual for scientific monitoring of seagrass habitat - Caribbean Edition. Durham, NH: University of New Hampshire, 2005. 74 p. 
SHORT, F. T.; KOCH, E. W.; CREED, J. C. MAGALHÃES, K. M.; FERNANDEZ, E.; GAECKLE, J. L. SeagrassNet monitoring across the Americas: case studies of seagrass decline. Mar. Ecol., v.27, p. 277-289, 2006.

STONER, A. W. Abundance, reproductive seasonality and habitat preferences of amphipod crustaceans in seagrass meadows of Apalachee Bay, Florida. Contr. Mar. Sci., v. 23, p. $63-77,1980$.

THORSON, G. B. Communities (sublittoral or shallow shelf). Ecology. Gel. Soc. Amer. Mem., v. 67, p. 461534, 1957.
WEBSTER, P. J.; ROWDEN, A. A.; ATTRILL, M. J. Effect of shoot density on the infaunal macro-invertebrate community within a Zostera marina seagrass bed. Estuar. coast. Shelf Sci., v. 47, p. 351-357, 1998.

WILSON JR., W. H. Competition and predation in marine soft-sediment communities. A. Rev. Ecol. Syst., v.21, p. 221-241, 1991.

(Manuscript received 20 March 2009; revised 05 May 2009; accepted 13 July 2009) 